\title{
MICHIGAN LAKES: An Assessment of Water Quality
}

\section{INTRODUCTION}

Michigan has more than 11,000 inland lakes, that provide countless recreational opportunities and are an important resource that makes tourism and recreation a \$15-billion-dollar per-year industry in the State (Stynes, 2002). Knowledge of the waterquality characteristics of inland lakes is essential for the current and future management of these resources.

Historically the U. S. Geological Survey (USGS) and the Michigan Department of Environmental Quality (MDEQ) jointly have monitored water quality in Michigan's lakes and rivers. During the 1990's, however, funding for surface-water-quality monitoring was reduced greatly. In 1998, the citizens of Michigan passed the Clean Michigan Initiative to clean up, protect, and enhance Michigan's environmental infrastructure. Because of expanding water-quality-data needs, the MDEQ and the USGS jointly redesigned and implemented the Lake Water-Quality Assessment (LWQA) Monitoring Program (Michigan Department of Environmental Quality, 1997).

\section{LAKE WATER-QUALITY MONITORING PROGRAM}

As part of the MDEQ’s “Strategic Environmental Quality Monitoring Program for Michigan's Surface Waters (Michigan Department of Environmental Quality, 1997), over 700 inland lakes in Michigan with public access will be sampled by 2015 . The data will be analyzed to assess and determine baseline and regional lake water-quality characteristics and trophic status. This assessment will determine whether the requirements of the Michigan Water-Quality Standards and Great Lakes Initiative are attained. The current data will be compared with historical data to identify changes in lake-quality characteristics and detect

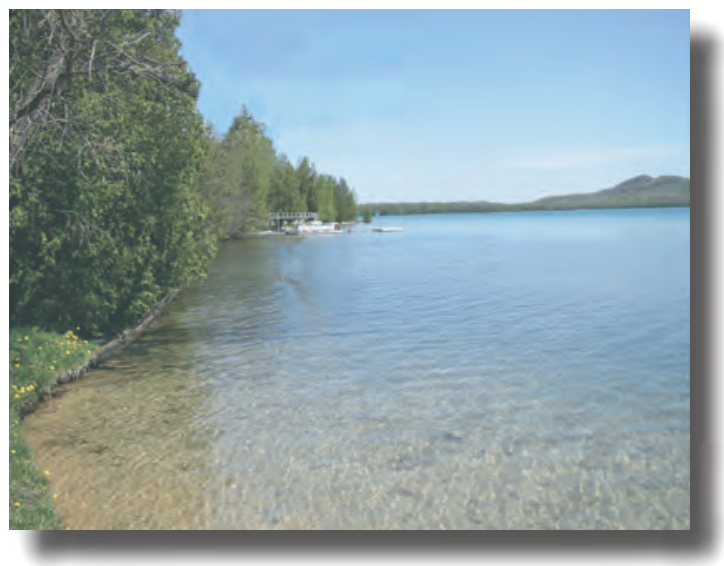

Michigan has more than 11,000 inland lakes. Photo by Sharon Baltusis.

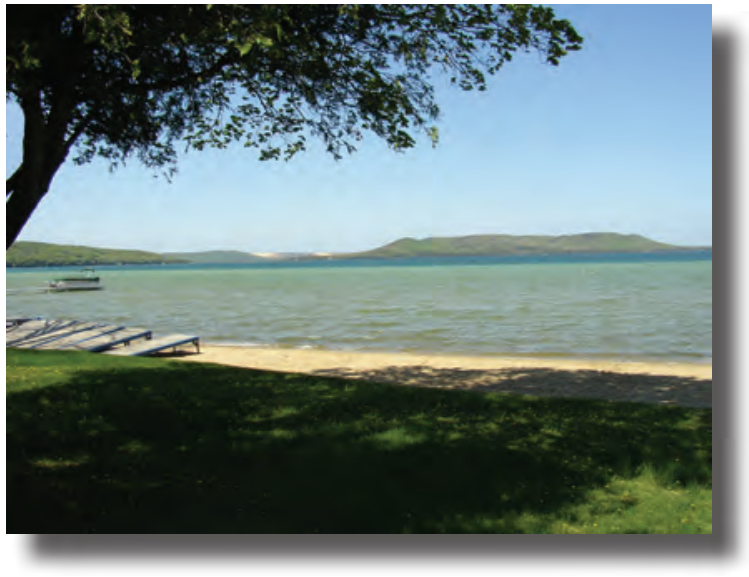

A view of Glen Lake in Leelanau County.

Photo by Sharon Baltusis.

possible trends. Trend data are important for measuring the effects of human activity on aquatic environments and determining whether water-quality protection programs are leading to longterm improvements. This program also will provide data to support MDEQ's water-quality permitting and assessment programs, and identify new and emerging water quality problems. Emerging water-quality problems include nutrient enrichment, which leads to accelerated eutrophication, and the occurrence of nuisance plant conditions or exotic species in a water body. Early warning of these potential issues through an effective monitoring program will allow action to be taken before major problems develop.

\section{MONITORING}

The LWQA monitoring program also is designed to integrate volunteer monitoring activities with Federal and State water-quality monitoring. The MDEQ, in partnership with the Michigan Lake and Stream Associations, Inc. (ML\&SA), developed the Cooperative Lakes Monitoring Program (CLMP) (Michigan Department of Environmental Quality, 1997) as a method for citizens to monitor water quality and to document changes in lake quality over time. The CLMP provides volunteers with sampling methods, training, workshops, technical support, quality control of sampling procedures, and laboratory assistance to monitor water-quality indicators in their lake. Field data from these programs then will be used to calibrate satellite imagery that will be used for estimating statewide lake water-quality characteristics and trends. All LWQA Monitoring Program data will be stored in the U.S. Environmental Protection Agency's data-management system STORET and in the USGS National Water Information System (NWIS). Data will be made available to the public through the Internet. 


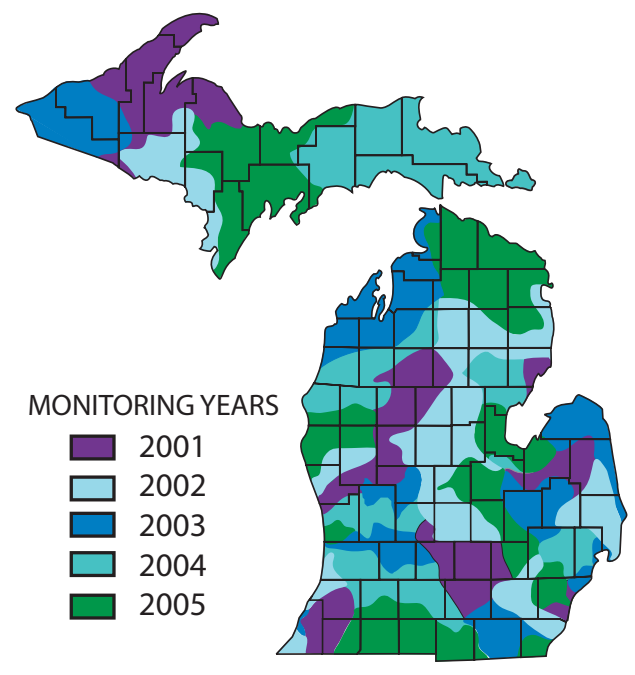

Michigan's water-quality monitoring units, 2001-2005.

\section{LAKE SELECTION}

Although knowledge of the water-quality characteristics of all lakes within the State would be desirable, field sampling of every lake is difficult. Therefore, lakes selected for monitoring were restricted to lakes 25 acres or larger, with public access. The total number of lakes meeting these criteria is more than 700 . Lakes sampled in a given year are selected randomly from 7 to 10 major watersheds throughout the State.

Specific watersheds are monitored in a 5-year cycle to assist in (1) statewide water-quality assessments, (2) the National Pollutant Discharge Elimination System (NPDES) permitting process, and (3) resource-management decisions. Lakes in various watersheds will be visited on three (5-year) rotations until all lakes in the study have been sampled. After 5 years, some lakes will have been sampled in all 45 major watersheds in Michigan (Michigan Department of Environmental Quality, 1997).

\section{LAKE-WATER SAMPLING}

All lakes selected for monitoring within a given year will be sampled once during spring turnover (usually April) and again in late summer (August and September) when the lake may be stratified thermally. Samples collected during spring turnover represent baseline water-quality characteristics of the lake because the water is well mixed. Samples collected in late summer, when the water is the warmest and plant growth is at its peak, will give insight into the biological productivity of the lake. As the lake water warms throughout the summer, a lake can stratify and water quality can vary appreciably with depth. Thermal stratification occurs during the summer in many Michigan lakes where a layer of less dense, warmer water is isolated from mixing with a deeper, more dense, colder layer. This condition is affected by the lake morphology, any inflow or outflow of water, and prevailing winds. Prior to each sampling, profiles of dissolved-oxygen concentration, water temperature, specific conductance, and $\mathrm{pH}$ are obtained at the deepest part of the lake basin to measure the variation with depth to determine if the lake is stratified.
Water clarity is measured with a Secchi disk. Water clarity will decrease with an increase of algae and sediment. Water samples will be collected from each stratum (differing lake layers) for chemical analysis and the uppermost stratum also will be analyzed for chlorophyll- $a$. Chemical analyses will include major ions (such as calcium, magnesium, and chloride) and various forms of nitrogen and phosphorus. These data are used to determine the lake's water-quality characteristics and to classify the lake's biological productivity (also referred to as "trophic status") using the Carlson Trophic-State Index (TSI) (Carlson, 1977).

The Carlson Trophic-State Index ranges from 0 to 100. Water clarity, total phosphorus near the lake surface, and chlorophyll- $a$ concentrations are used in the index calculations. The low end of the scale represents low biological productivity (oligotrophic), the high end represents a very biologically active lake (eutrophic), and the highest end of the scale represents excessive biological productivity (hypereutrophic). The middle of the scale represents moderate biological productivity (mesotrophic).

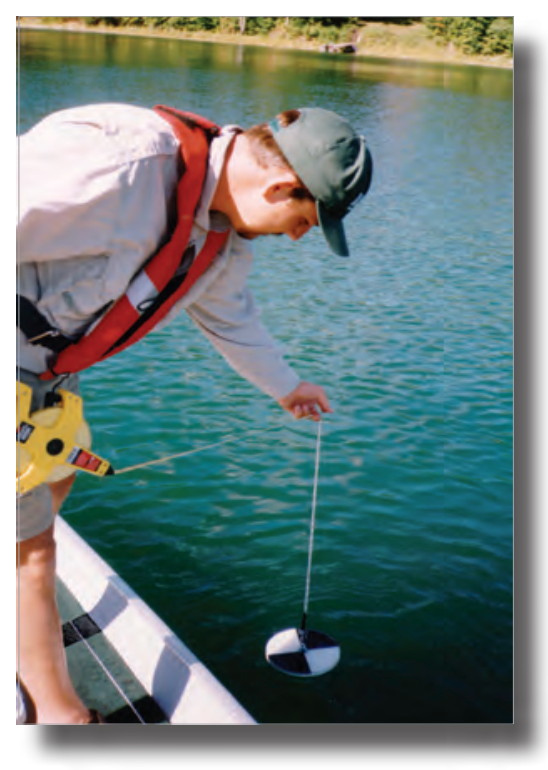

USGS scientist measuring the transparency of water using a Secchi disk. Photo by Russ Minnerick.

\section{LAKE STRATIFICATION}

The thermal stratification observed in Shupac Lake is typical of many deep-basin lakes found in Michigan. The water temperature in Shupac Lake gradually decreases with depth until about 28 feet, where a thermal barrier (thermocline) is formed that separates the upper stratum (epilimnion) from the much cooler water in the lower stratum (hypolimnion). Strata conditions can occur because water is densest at $4.0^{\circ} \mathrm{C}$. This thermal barrier will remain until fall when surface-water temperature begins to cool and, aided by wind action, the lake water will mix (fall overturn). In the spring, this process occurs again (spring overturn) when the ice first leaves the lake and the cold surface water begins to warm. When the water at $4.0^{\circ} \mathrm{C}$ sinks, aided again by wind, the lake water again will mix. Thermal strata will develop through the summer and the cycle will begin again. The metalimnion layer is defined by 


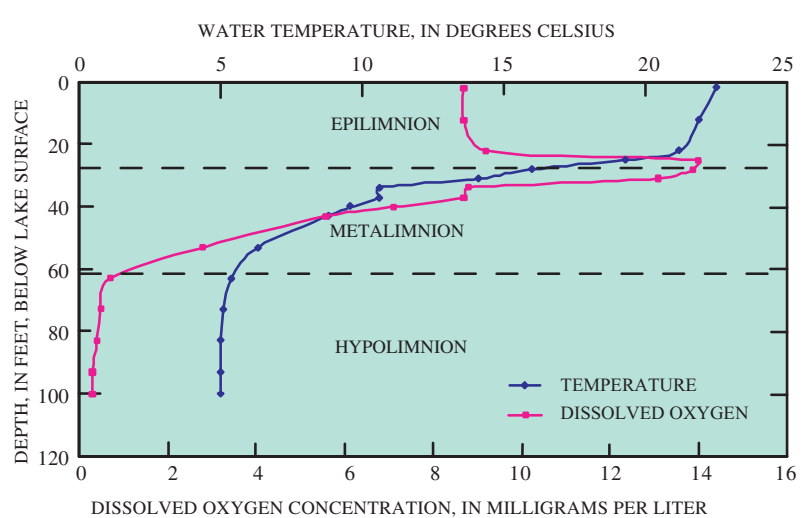

Temperature and Dissolved Oxygen profiles for Shupac Lake near Lovells, Michigan, August 28, 2002.

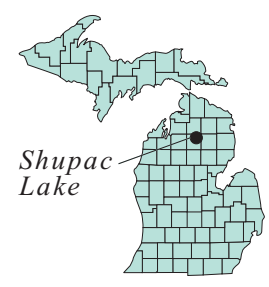

rapidly changing temperatures. This layer allows unique physical and chemical processes to occur within each stratum that will affect the cycling of nutrients and other elements within the lake.

The highest dissolved-oxygen concentration usually is found at the top of the metalimnion. It is in this zone that high concentrations of free-floating algae termed "phytoplankton" can occur. With sunlight penetrating to these depths, oxygen produced through photosynthesis is at its maximum. The oxygen supply below the metalimnion stratum is gradually used by bacteria in the decomposition of organic matter. The consumption of oxygen continues as additional dead plant and animal matter sinks to the lower stratum to be decomposed. Oxygen in the lower stratum will continue to be depleted until replenished by mixing with oxygen from the upper stratum during spring and fall overturns or a strong wind storm.

\section{PRODUCTIVITY OF LAKES}

A healthy, biologically productive lake is desirable for many activities such as fishing and attracting wildlife. A lake can be overly productive, however, when excessive nutrients such as nitrogen and particularly phosphorus are introduced. In excessive amounts, these nutrients will cause abundant plant growth and algal blooms. Eventually, if the excessive growth goes unchecked, oxygen will be depleted and the overabundance of aquatic growth may impair the utility of the lake for activities such as boating, fishing, and swimming. Accelerated introduction of nutrients into a lake usually is a result of man's activities in the watershed. Poor agricultural practices, failing septic systems, and increased runoff associated with residential development are the leading contributors to nutrient introduction. Increasing lake productivity due to nutrient enrichment is of great concern to lake-resource managers.

\section{HOW MANY NUTRIENTS ARE TOO MUCH?}

Often, it only requires small additional quantities of nutrients above those that are found naturally to increase a lake's productivity to the point where eutrophication becomes a concern. The nutrient in the shortest supply will tend to be the limiting control on production of shoreline plants, phytoplankton, and other algae (Hem, 1985). In Michigan, total phosphorus levels greater than $0.020 \mathrm{mg} / \mathrm{L}$ are considered indicative of eutrophic conditions (Ralph Bednarz, Michigan Department of Environmental Quality, oral commun., 2003). Typically, phosphorus is considered the limiting nutrient in lakes in this region, although increased phosphorus and nitrogen concentration can have a greater combined effect on plant growth than either nutrient alone in some lakes (Elser and others, 1990).

The size and depth of a lake will help determine how the chemical and biological processes in the lake will respond to an increase of nutrients. A deep lake, with a steep shoreline gradient, will limit light penetration that is needed for plant production and growth. A shallow lake that would allow sunlight to reach its entire bottom is susceptible to algal blooms and plant growth. Lakes with deep basins and a small epilimnion to hypolimnion ratio generally have oligotrophic characteristics (Cole, 1983).

Shallow lakes with abundant rooted aquatic plants and attached algae may have measured nutrient levels during the summer months which are lower than other productive lakes with less aquatic plant growth. Aquatic plants act as a "lock box" for nutrients. These plants utilize large amounts of nutrients from the water during the growing season. As these plants mature and die, they sink and become part of the organic matter on the lake bottom. When physical and chemical conditions are right, the decomposition of this organic matter releases many of the nutrients that were bound in the plant tissue. The recycling of these nutrients into the lake water creates a potential for additional algal blooms.

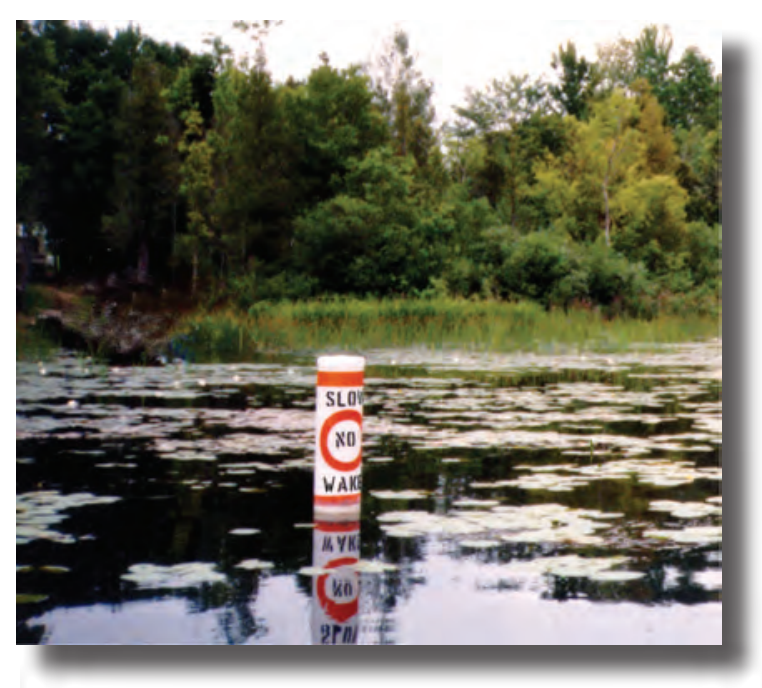

Aquatic plant growth and algae may impair lake activities. Photo by Russ Minnerick. 


\section{MEASURING WATER CLARITY FROM SATELLITE IMAGES}

Water clarity in a lake is correlated closely with water-quality and trophic status. Although scientists can accurately measure the clarity of lake water through laboratory analysis and by physical measurements using tools such as a Secchi disk, it is difficult to gather these data types on every body of water in the State, particularly over a period of time long enough to detect waterquality changes.

The USGS, the MDEQ, and Michigan State University's Regional Earth Science Application Center (RESAC) collaborated on estimating the trophic status of unsampled lakes using multi-spectral imagery from the LandSat 7 satellite. The reflectivity in satellite images of inland waters compares well with Secchi disk measurements (Olmanson and others, 2000). Mathematical models are being developed to estimate lake clarity in unsampled lakes, which is a key measurement in the calculation of the Carlson TSI from satellite images. The Secchi disk data collected in lakes throughout the State by USGS and MDEQ scientists and citizen volunteers will be used to calibrate the satellite remote-sensing imagery. Once calibrated, the remotesensing technique will allow the rapid assessment of all lakes over 25 acres in the State, with little additional cost to the LWQA Monitoring Program.

\section{CONCLUSIONS}

Data and analysis from the LWQA Monitoring Program will provide lake-resource managers with tools to evaluate the current water-quality conditions of selected lakes, potential water-quality problems, and to help determine changes that may be occurring in inland lakes. With these data and analysis, resources can be directed toward addressing potential and identifiable lake water-quality problems in the State. Baseline data can be used to determine the effectiveness of past and present resourcemanagement practices for Michigan lakes.

\section{REFERENCES}

Carlson, R.E., 1977, A trophic state index for lakes:

Limnology and Oceanography, v. 22, no. 2,

p. 361-369.

Cole, G.A., 1983, Textbook of limnology (3rd ed.): Prospect Heights, IL., Waveland Press, 401 p.

Elser, J.J., Goldman, C.R., and Marzolf, E.R.,1990, Phosphorus and nitrogen limitation of phytoplankton growth in fresh waters of North America- A review and critique of experiment enrichments: Canadian Journal of Fisheries and Aquatic Sciences, v. 47, no. 7, p. 1468-77.

Hem, J.D., 1985, Study and interpretation of the chemical characteristics of natural water (3rd ed.): U.S. Geological Survey Water-Supply Paper 2254, 263 p.
Michigan Department of Environmental Quality, 1997,

A Strategic Environmental Quality Monitoring Program for Michigan's Surface Waters: MI/DEQ/SWQ-96/152, p. 7-39.

Olmanson, L.G., Kloiber, S.M., Bauer, M.E., Day, E.E., Brezonik, P.L., 2000, Upper Great Lakes RESAC

lake water quality image processing protocol: Water Resource Center and Remote Sensing Laboratory, University of Minnesota, St. Paul, $\mathrm{MN}, 11 \mathrm{p}$.

Stynes, D.J., 2002, Michigan Statewide Tourism Spending and Economic Impact Estimates: Accessed November 20, 2003 at URL http://www.prr.msu.edu/ miteim/MichiganSatExec.pdf

— By R.J. Minnerick

Graphics and layout by S.B. Baltusis and R.S. Jodoin.

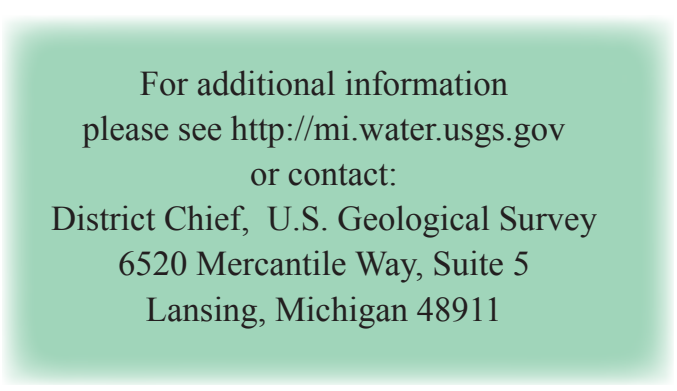

Prepared in Cooperation with Michigan Department of Environmental Quality

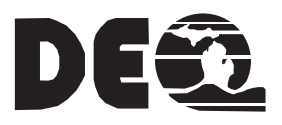

